\title{
Popular Music, National Culture and the First Chervona ruta Festival of 1989
}

\author{
Bohdan Klid \\ Canadian Institute of Ukrainian Studies, University of Alberta
}

\begin{abstract}
This article examines the origins, organization and goals of the first Chervona ruta music festival against the background of the perestroika period, which was characterized by a deepening anxiety over the plight of Ukrainian culture. In 1988 Ivan Dziuba gave voice to these issues in an essay that, among other things, pointed to the shortcomings of Ukrainian pop culture. The present paper shows how, in its own way, the festival became a response to such concerns, and how the problems and limitation of the festival itself reflected the serious cultural situation in Ukraine.
\end{abstract}

Keywords: Popular music, Chervona ruta, festivals, Ivan Dziuba, cultural politics.

O n September 19-24, 1989 the first Chervona ruta festival of Ukrainian contemporary song and popular music was held in Chernivtsi, Ukraine. ${ }^{1}$ Although it was a noteworthy event in the life of preindependence Ukraine, the scholarly literature has tended to stress the festival's connection with, and role in, the Ukrainian national movement during the perestroika period. The political nature of a number of songs performed at the festival was noted. Moreover, the festival itself became a venue for openly expressing Ukrainian patriotism and national feelings. Yet, the festival also became an important event in Ukrainian cultural life of that period. Due to the performance of Ukrainian-language rock and other popular songs that were previously largely unknown (or known only in small counterculture and underground circles), the festival became an event that symbolized a renewal of Ukrainian-language popular culture, which contemporaries viewed as stagnant and backward. Although this has

1 Chervona ruta is a plant of the monarda species that goes under such common names as bee balm, horsemint, oswego tea, and bergamot. The festival itself was named after the title of a pop song of the same name, written by Volodymyr Ivasiuk in 1970, which became a hit not only in Ukraine and the Soviet Union, but also in the Ukrainian diaspora. Since then, the festival has been held biennially and remains a prestigious event known for promoting new talent and Ukrainian-language popular music. 
been mentioned to some degree in the existing literature, it is an aspect that will be of special focus in this paper. ${ }^{2}$

In particular, the aim here is to examine the origins, organization and goals of the festival organizers in the context of the existing impasse that Ukrainian popular culture found itself in at the beginning of the perestroika years. This was a period during which important political and economic changes were beginning. They led to the breakup of the Soviet Union and the destruction of its command economy. These were also the years during which important cultural questions were raised and debated. It was a time when the Ukrainian intelligentsia often raised issues related to the plight of the Ukrainian language and Ukrainian-language culture. Ivan Dziuba's "Do We Comprehend National Culture as a Single Whole?" (Jan. 1988) was an important early essay in this vein and came to be associated with the Chervona ruta festival. ${ }^{3}$ This paper will, among other things, also examine whether festival organizers succeeded in achieving their goals in light of the issues raised by Dziuba.

Ivan Dziuba described Ukrainian culture as incomplete and identified the impediments it faced functioning as a full-fledged system. He called on Ukraine's intellectuals to consider the interconnectedness of the various arts and how they complement and interact with one another (Dziuba, Nauka i kul'tura: Ukraina, 309-13). Among other things, Dziuba directed attention to popular culture (313). A complete national culture, he wrote, needed Ukrainian-language forms of mass culture. Whereas intellectuals tended to focus on high forms of culture alone, Dziuba argued that they could not survive on their own. He chastised his colleagues for being particularly inattentive to youth subcultures, even accusing them of acting like doctrinaire Savonarolas for their snobbish attitudes. With respect to rock music, Dziuba noted with approval that the Baltic states and Belarus were receptive to youth culture and that as a result national forms of rock music were developing there (321-22). Moreover, Dziuba was troubled by the weakness of Ukrainian culture in some regions of Ukraine, especially the "alienation" of large numbers of urbanites from the Ukrainian language itself. He noted that local events and artistic groups were often neglected,

2 In English, see Wanner Burden of Dreams, esp. 121-40; Wanner "Nationalism on Stage"; Bahry, esp. 250-51 and 254-57. In Ukrainian, see Riabchuk; Lepsha; Rutkovs'ka, "Polemichni..."; Cherkashyna. These four articles appeared within a year of the festival.

3 "Chy usvidomliuiemo my natsional'nu kulturu iak tsilisnist'?" was first published in Kultura i zhyttia. A slightly amended version was republished in the annual Nauka i kultura: Ukraina. All references are to the latter source. 
never entering the national cultural orbit. At the same time Ukrainian cultural achievements outside of Ukraine's borders were ignored (323).

While the ideas and concerns voiced by Dziuba had no direct connection to the origins of the Chervona ruta festival, they were an integral part of the intellectual atmosphere that led up to it. This is evident from what the actual organizers of the event, Taras Mel'nyk and Anatolii Kalenychenko said when they began promoting it. ${ }^{4}$ Iryna Lukoms'ka and Liia Il'chenko claimed that the idea for the festival belonged to Mel'nyk, Kalenychenko and Oleh Repets'kyi, all students at the Kyiv Conservatory, who were later joined by Kyrylo Stetsenko, also a Kyiv Conservatory graduate (Lukoms'ka and Il'chenko). Mel'nyk and Kalenychenko, joined by the poet Ivan Malkovych, provided an analysis of the problems facing Ukrainian popular music and explained the need for holding a large-scale festival of contemporary Ukrainian popular music to begin rectifying these problems. This was done in a full-page newspaper article titled "Towards an Encounter with Chervona ruta: The Creative Concept of the First Republicwide Festival of Ukrainian Contemporary Song and Popular music."5 A short appeal from the festival organizing committee (titled "Zvernennia"), addressing Ukrainians at home and abroad, appeared alongside. An analysis of these two documents is useful since they shed light on the rationale behind the festival and reveal parallels to Dziuba's ideas. ${ }^{6}$

The three authors began with a grim assessment: Ukrainian popular music was facing extinction because songwriters and performers were avoiding the Ukrainian language in their lyrics. (Although not stated explicitly, it was assumed they preferred Russian.) The natural development of Ukrainian popular music was being impeded because of a

\footnotetext{
${ }^{4}$ Anatolii Kalenychenko in a letter to this author acknowledged that Dziuba's article "made a great impact on us, because it formulated that which we felt intuitively in regard to Ukrainian culture-especially the proposition that mass culture was an organic component of all culture [and] in its absence or weakness, culture [was] incomplete or substandard..." March 5, 2008. See also Ievtushenko 255.

5 The article was published in the spring and summer of 1989 under several different titles, in both national and regional newspapers, as well as in a pamphlet co-published by the Central Committee of the Young Communist League of Ukraine (Komsomol) and the festival organizing committee. Kultura i zhyttia published it as "Nazustrich "Chervonii ruti': Tvorcha kontseptsiia Pershoho respublikans'koho festyvaliu ukrains'koi suchasnoi pisni ta populiarnoi muzyky." A slightly different version, titled "Chervona ruta," appeared in Literaturna Ukraina. The official version was published as Chervona ruta 89.

${ }^{6}$ All further references to the article and to the appeal come from Kultura i zhyttia, July 161989.
} 
superficial understanding of what was 'national'; in other words, it was equated with the ethnographic. Ukrainian popular music also ignored contemporary life and the burning issues of the day, largely limiting itself to lyrical and romance styles. These factors were turning Ukrainian pop music into a provincial phenomenon; it was old fashioned and anachronistic. By not meeting the expectations of young people, music was alienating them from Ukrainian-language songs and Ukrainian culture in general, which was seen to be inherently traditional and archaic. Instead, Ukrainian youth tended to listen to Russian-, English- and Italian-language pop music (Mel'nyk, Kalenychenko, Malkovych, Kultura i zhyttia 6).

The authors laid the blame for these problems not on the national culture but on the anachronistic forms of its embodiment. There was an obvious need to create a more contemporary version of Ukrainian popular music, they said. Unfortunately, the way forward was not clear. The authors outlined two approaches that had been discussed by others to remedy the situation. One amounted to a conservative-nativist argument; the other was a liberal-cosmopolitan prescription. The first contended that Ukrainian musicians should follow in the tradition of Volodymyr Ivasiuk (1949-1979), a musician-composer who had attained great popularity in the early 1970s. The sounds of that era were to serve as a model. The three authors dismissed this approach offhand, saying that each epoch required its own songs, melodies and rhythms. The second solution suggested that Ukrainian pop musicians should orient themselves on the newest styles and directions of Western music. Here, the authors went into a lengthy discussion.

Ukrainian pop musicians, they acknowledged, had to become familiar with world trends and practices. However, incorporating the newest styles raised the danger of "mere copying" (Mel'nyk, Kalenychenko, Malkovych, Kultura i zhyttia 6). Moreover, mindless imitation of foreign models would inevitably lead to a loss of national character. This would place Ukrainian popular music at the tail end of Western music, resulting in continuous repetition and dooming Ukrainian musicians to eternal backwardness, a secondary role and artistic inferiority. At this point, the authors declared:

Ukrainian popular music faces a task of great historic weight: to create a genuinely contemporary, deeply national style in popular music. For this to occur what is needed, on the one hand, is to purge the old-fashioned pseudonational layers from the national, revealing its true face, and, on the other, to free itself from the burden of the canons of western pop music, and to link the national with the contemporary (6).

In other words, Ukrainian popular music might escape its second rate status not by taking up ready-made forms and genres from the West, or by imitation, but by forging its own way, mindful of world achievements, while 
proceeding from its own national musical experience. The authors cited historical precedents from other countries and cultures: the AngloAmerican break with European pop in the 1940s and 1950s; the American pop sound of the 1960s and 1970s based on Afro-American music; and the Italian pop songs of the 1970s and early 1980s.

In short, the authors posited that by turning to Ukrainian tradition, musicians would be able to innovate. The goal was to rethink Ukrainian music in contemporary terms, but also to enrich it with Ukrainian folk tradition. This approach, they reasoned, would not only overcome the provincialism of Ukrainian popular music but shift innovation in a national direction, creating a contemporary, national style that would be attractive at home and competitive internationally.

The first step in remedying the dire situation would be the holding of a republic-wide festival of contemporary popular music in Chernivtsi, the birthplace of Volodymyr Ivasiuk. The festival would be called Chervona ruta, the title of one of his most popular songs. Musicians would be encouraged to strive for originality, to avoid commonplace and mainstream styles, and to master new trends, genres and modes of performance. In identifying the festival as "national," the authors also insisted that only Ukrainian-language songs be allowed in the competition. Russian-language performers, they argued, had opportunities to appear at many venues and, therefore, Chervona ruta needed to be an exclusively Ukrainian-language event.

The basic organizational framework of Chervona ruta was outlined in a much shorter appeal, published under the auspices of the festival organizing committee. Here the festival was described as a competition of individual singers as well as groups that would compete in one of three basic genres or styles: (1) pop music in all its forms, including romances and arrangements of folk songs; (2) bard songs (i.e., compositions by balladeers or singer-songwriters); and (3) rock music. Anyone over the age of forty was excluded from the competition, as were individuals who had previously won prizes at contests beyond the oblast'-level, and those who had received official recognition from the state i.e., those who had titles of "distinguished" or "people's" artist (zasluzhenyi or narodnyi artyst Ukrainy). Eligibility would be determined at preliminary oblast'- or regional-level, competitions. Invitations would also be extended to performers and groups outside Ukraine, but these would not have the privilege of competing.

Festival organizers obviously wanted to reach out to as many young people as possible and attract new talent from all parts of the country. Regional-level competitions were to determine three winners in each of the three categories. Lviv and Kyiv-as centres of Ukrainian-language musicwere allowed to send their top six in each category. 
It was at the regional (oblast') level that significant misunderstandings and organizational problems first surfaced. It became clear that interest and support for the festival varied widely throughout Ukraine, as did the number of Ukrainian-language groups and singers who entered the various competitions, not to mention the quality of their material and performances.

Lviv was the first city to hold an oblast'-level contest on May 6-8, 1989. Prior to this, however, representatives of the national festival organizing committee in Kyiv accused the oblast' committee of not advertising the event and of failing to explain the underlying principles of the festival properly; reservations were also expressed about jury members (Mishchenko). As a result, an additional competition was scheduled (Chavaha).

Kyrylo Stetsenko, a member of the national Chervona ruta festival committee, explained that Lviv played a leadership role in Ukrainianlanguage culture and therefore the national committee reserved the right to modify the city's entrants to the Chernivtsi festival, given the number and quality of the applicants. In Lviv, there had been 80 entrants in the pop music category alone-many of which were quite talented-yet only six were chosen. Furthermore, some good performers, e.g., bards linked to the cabaret group Ne Zhurys' (Don't Worry), did not participate. This may have been due to poor information about the festival and about the prerequisites for entering the competition (Mishchenko). As well, Stetsenko explained that some rock groups may not have entered the competition because they believed it to be either "a planned event in the struggle against "bourgeois counterculture'" or were frightened off by the high average age of the jury and its purported negatives attitudes toward rock music (Stetsenko, "Chervona ruta'," 5). As a result of the skeptical attitude by some performers and the absence of others, a second competition took place on July 29, 1989, resulting in six performers being chosen in the "bard" category and three in the "rock music" category. Stetsenko, who was a member of the jury, observed that the level of competition in the city was higher than in the oblasts (Derkach).

The Lviv events showed that some organizational problems were the result of inertia and the conservatism of local officials. They also revealed that in the Lviv region, which was a bastion of Ukrainian-language popular culture, there were many talented individuals and groups. By virtue of their skills and level of performance, they gained disproportionate access to the Chernivtsi competition, which led to accusations of favouritism (see, for instance, the criticism by Fedorov).

While the difficulties in Lviv were caused by an overabundance of talent, in the oblasts the problems were generally of a different nature. In 
Dnipropetrovsk about 40 groups and individual singers participated in the regional competition. A reporter covering the event for a local newspaper commented that contestants adhered to a standard presentation of traditional folklore, which was old fashioned. The correspondent also noted that attitudes of the jury to rock music were negative, even confrontational (Ilin).

In some cities the turnout for the competition was extremely low. In Mykolaiv there were only seven contestants; in Vinnytsia just two (Kupchenko); in Zaporizhzhia there were eight (Zvoryhina); in Voroshylovhrad (now Luhansk) there were just two contestants, who performed traditional songs; ${ }^{7}$ and, in Khmelnytsk there were only ten in the audience and just four of eleven jury members showed up (Arion 7).

In late July the national committee reported that of the nine oblasts that had held contests, only three of them took place without problems. The situation was especially troubling in Kirovohrad, Chernihiv and Ukraine's south, where festival organizers reported that they were told that the oblasts were largely Russian-speaking, and that there was no place for Ukrainian popular music or folklore (Kutsai 1). In Odesa, preparation for the competition began only a few days before the event. In a field of eight contestants, there was only one candidate from the rural areas; the audience numbered twenty. Members of the Taras Shevchenko Ukrainian Language Society were prevented from sitting on the organizational committee or jury and were not allowed to speak at the end of the concert, even though the society was a festival co-sponsor (Petrovs'kyi et al. 1).

Kyiv was the last centre to hold a competition on August 18-20, which was well publicized in advance by the local, regional and national press (Sharykova; Sheremet 3; Stetsenko, "Kyiv zustrichaie"). The Kyiv competitions differed from the others in two ways. First, an additional competition was held for those from other parts of Ukraine who were not able to compete in their own regional competition. Second, a nation-wide contest to determine the best emcees or festival hosts was also held. In total, Kyiv chose 18 entrants for the finals, six in each genre. Most notable at the Kyiv competitions, according to Stetsenko ("Kyiv zustrichaie"), were the performances of Kyiv's rock groups, who showed both sophistication and diversity of styles. However, only 200 to 400 people attended the event despite adequate advertising. Stetsenko blamed this on the lack of prestige

\footnotetext{
7 Oleh Vol's'kyi, from the national organizing committee, frustrated at the lack of support by local organizers, called the event in Voroshylovhrad "a profanation of the very idea of 'Chervona ruta'." See Shtan'ko.
} 
Ukrainian-language songs had among youth (Stetsenko, "Kyivs'ka uvertiura" 3).

As mentioned, the Chervona ruta festival ultimately took place on September 19-24 in Chernivtsi, but it was held in an atmosphere of great tension as local authorities had assembled large numbers of uniformed police and civilian-clothed security personnel to confront, intimidate, and, in some instances, to threaten and even assault festival goers, performers and organizers (Kryvenko). ${ }^{8}$ The local authorities were correct in their assessment that the five-day event would be more than just a music festival. The open display of national feelings, both among spectators and performers, were the most obvious manifestation of the politicized nature of the event, which also had political consequences. Mykola Riabchuk (401) noted that following the festival the Chernivtsi oblast' party secretary was removed from his post and that the people of Chernivtsi were transformed into a civic force for change. Most importantly, though, despite the intimidations, the planned events did take place, and the festival was immediately recognized as a success.

Reports during and shortly following the festival often mentioned innovations and breakthroughs related to popular music, especially in the rock category, and noted that at least some of the goals set out by the festival organizers were achieved. One correspondent commented, "the festival showed that the Ukrainian song not only exists-it has its own bright colours and originality" (Syliutina 5). Another wrote, "Ukrainian pop and rock do exist. And it is impossible not to notice them following the festival" (Stohniienko). "The main conclusion of the festival... [is] that rock musicians are at work in Ukraine..., [they] are equal to leading groups from the Leningrad, Sverdlovsk rock-clubs, Moscow's rock-laboratory" (Tosenko).

Festival organizers were perhaps more ecstatic. Ivan Malkovych declared, "The myth about the impossibility of [the existence of] Ukrainian rock music was shattered" (Kobets'). Taras Mel'nyk commented that festival outcomes exceeded his expectations and that new directions in pop music were created in a very short period of time (Bezsmertnyi). Anatolii Kalenychenko concluded that much had been accomplished at the festival in linking the "national" to the "contemporary" (Bezsmertnyi).

Defenders and critics of the festival were split for the most part along ideological lines. Official criticism, sanctioned by Ukrainian Communist party and government officials, was published in Pravda Ukrainy. Besides criticizing the outpouring of political and national feelings at the festival

\footnotetext{
${ }^{8}$ See also the reprint of 0 . Kryvenko's article: Kryvenko, "Festyval' prokhodyv..."
} 
and in some of the songs, the organizers were criticized for excluding Russian, Moldovan and Jewish songs. The author also charged that favouritism was shown to performers from Lviv, pointing to the number of awards won by Lviv performers as well as to the size of the contingent, which he claimed approached almost $50 \%$ of the total number of participants (Fedorov). ${ }^{9}$ Criticism that reflected traditional-nativist views came from bureaucrats in the Ministry of Culture. For instance, 0. Rutkovska from the Ministry wrote that although folklore ensembles came from many oblasts of Ukraine, they were not given a prominent role at the festival. Another criticism leveled against the festival was that not enough of Volodymyr Ivasiuk's most popular songs were performed. Finally, traditional songs, such as those written by Ukraine's classical and modernday poets "were drowned out by the wails of trans avant-garde rock, the insignificant [words] of the bards, the satirical couplets with idiot heroes." (Rutkovska; see also Budzeshen).

Mykola Riabchuk offered the most sophisticated defence and analysis of the festival and its outcome. To understand why Chervona ruta had become a peculiar symbol of both the cultural and national rebirth of Ukraine, he wrote, one had to pay close attention to the context in which the festival was held. First, there was the political situation. Volodymyr Shcherbyts'kyi's regime in Ukraine had been attempting to freeze the perestroika processes. Second, there was the cultural situation, which was characterized by a decline in the use of the Ukrainian language in all areas of public life, including music, driving Ukrainian cultural activity either to the periphery or underground (Riabchuk 396-400). The Chervona ruta festival thus provided a new and public venue. Riabchuk, referring to Dziuba's analysis, concluded that the Chervona ruta festival was a step forward toward a more normal, holistic functioning of Ukrainian culture and language $(401-402,404)$. The validity of Dziuba's analysis concerning the crisis of Ukrainian-language popular music was recognized by festival organizers, when they printed an excerpt from his article in the festival booklet (Stetsenko, comp., Pershyi).

Another analysis of the festival, written by L. S. Cherkasyna, also made reference to Dziuba, albeit to a different article. ${ }^{10}$ Like Riabchuk, she

\footnotetext{
9 Some of Fedorov's charges were gross exaggerations or simply misleading. For example, the $50 \%$ figure given by Fedorov for Lviv performers was actually under $20 \%$. Of the total of 156 entrants, 31 came from Lviv. Fedorov also claimed that Ivano-Frankivsk and Ternopil oblast performers were favoured. The author probably intended to show that the festival was dominated and controlled by Galician Ukrainians.
}

10 Dziuba, "Strazh cheloveskogo...." Here he discusses the provincial character of 
concluded that that the idea behind the festival, as well as the way it was realized, represented a complex, multi-faceted way of overcoming Ukrainian cultural provincialism, its sense of incompleteness and geographical isolation (41). As noted above, the organizers made an attempt to reach out to all oblasts and succeeded to a certain degree in achieving broad regional representation. Bands and individual musicians and singers attended from outside of Ukraine as well-from Europe, other Soviet republics, and the Americas-performing at a special concert.

Numerical data give an indication of the overall strengths and weaknesses of Ukrainian popular music in this period, while showing sharp regional disparities. The pop music category was best represented at the festival, accounting for 78 ensembles or individual singers; there were 48 bards or balladeers, but only 30 rock groups. Out of 156 entrants, 31 were from Lviv and 21 from Kyiv, meaning that these two cities made up exactly one third of all contestants. Significant delegations came from Chernivtsi (14) and Ivano-Frankivsk (13). A total of 79 (slightly more than 50\%) of all entrants, therefore, came from just four oblasts (largely from western Ukraine and the capital region) in a country that had twenty-six. Donetsk, Dnipropetrovsk, Rivne, Ternopil, Volyn, Mykolaiv and Cherkasy oblasts sent from five to nine entrants each. Worst represented (with only one contender each) were Voroshilovhrad (today, Luhansk), Kirovohrad, Chernihiv and Poltava oblasts ("Tilky tsyfry..." 1). Not surprisingly, the overwhelming majority of festival prizewinners were from Lviv and Kyiv oblasts. ${ }^{11}$ The uneven geographic representation of Ukrainian popular music and, by extension, of Ukrainian popular culture and language, was thus made obvious. Attempts were made to address these regional imbalances by holding subsequent Chervona ruta festivals in eastern and southern Ukraine (Zaporizhzhia, 1991); Donetsk, 1993; Symferopil, 1995; Kharkiv, 1997), which were and still are heavily Russified.

Ukrainian literature and culture in detail (see 31-44).

11 Two of three second-place winners in the pop music category were Lviv oblast' entrants and one of two were third-place winners. (No first-place winner was chosen.) In the rock group category, Lviv's Vika Vradii took first place, while Kyiv's "Komu vnyz" and Lviv's "Braty Hadiukyny" shared second place. Kyiv's "Zymovyi sad" shared third place with Lutsk's "NZ." In the bard or balladeer category, Lviv's Viktor Morozov shared top spot with Cherkasy's Eduard Drach, while Mariia Burmaka of Kharkiv and Andrii Panchyshyn of Lviv shared second place. (Third place was not awarded.) Lviv bard Vasyl Zhdankin was awarded the festival's grand prize. 


\section{POSTSCRIPT}

As noted, the first Chervona ruta festival took place during a time of political and cultural change. It was also a time of economic transformation. Songs that were performed on stage were recorded by the Ukrainian-Canadian joint venture company "Kobza," which mass produced cassette tapes of the songs and distributed them across Ukraine. This marked a first attempt at widespread distribution by a non-state entity in Ukraine, which succeeded in promoting Ukrainian contemporary popular music countrywide. It also marked the beginning of the commercialization of Ukrainian-language popular music and of a rudimentary music business. ${ }^{12}$

More importantly, the festival served as a launch pad for many popular singers and groups, who subsequently made successful careers as professional singers and musicians. Among the first were the rock bands "Braty Hadiukyny" and "Komu vnyz" and the rock singer Vika Vradii. Taras Chubai and his band "Plach Ieremii" achieved popularity following the 1991 festival in Zaporizhzhizia. The well-known pop singers Oleksandr Ponomariov, Ruslana Lyzhychko, and Ani Lorak began their highly successful professional careers following the 1995 festival in Sevastopol. The 1997 Kharkiv festival marked the debut of the successful hip-hop groups "Tanok na maidani Kongo" and "Tartak." It is in the area of nurturing and promoting new talent that the organizers of the Chervona ruta festivals had their most notable success (Ievtushenko 256-57).

The efforts to bring Ukrainian contemporary popular music to eastern and southern Ukraine, by holding Chervona ruta festivals in heavilyRussified cities of the country-starting with the 1991 festival in Zaporizhzhia-did not, however, lead to wide playing or listening of Ukrainian-language rock or pop in these regions. This is in part a reflection of the still dominant presence of the Russian language in popular culture and daily life in most of Ukraine's large cities, including Kyiv. Even today, many FM stations in Ukraine's large cities of central and south-eastern Ukraine play mostly Russian-language pop and shanson (blatnye pesni).

The year 2014 marks the twenty-fifth anniversary of the Chervona ruta festival. This makes it the longest-running non-commercial music festival of Ukrainian-language contemporary and popular music. The competition format has been maintained, including the holding of oblast'-level competitions where selections are made to determine entrants that

12 Oleh Repets'kyi, one of the initiators of the festival, was the first general director of "Kobza" (See Bilyk 1; Tsvirko 3). Repets'kyi in 1992 co-founded a BritishUkrainian joint venture recording studio "Komora," which is still in existence today $(<$ www.komora.com $>$ ). 
compete in the nation-wide festival. Whereas in 1989 , competitions were held in three categories, today there are six: popular music, dance music, rock, acoustic music, other music and authentic folklore. In March 2014 oblast'-level competitions began for the next national festival, which will be held in 2015.13

\section{Works Cited}

Arion, Halyna. "Povertaimosia do vytokiv svoikh." Korchahinets' 13 Aug. 1989: 7. Print.

Bahry, Romana. "Rock Culture and Rock Music in Ukraine." Rocking the State: Rock Music and Politics in Eastern Europe and Russia. Ed. Sabrina Petra Ramet. Boulder, CO: Westview Press, 1994. 243-95. Print.

Bezsmertnyi, Ivan. “Dumaimo pro druhyi krok." Molod' Ukrainy 30 Nov. 1989: n. pag. Print.

Bilyk, Oleksandr. "Oleh Repets'kyi, heneral'nyi dyrektor ukrains'ko-kanads'koho spil'noho pidpryiemstva 'Kobza." Vechirnii Kyiv August 4, 1990: 1. Print.

Budzeshen, L. "Uroky na maibutnie." Kul'tura i zhyttia 15 Oct. 1989: 3. Print.

Chavaha, K. "Vas chekaie 'Chervona ruta.'” Lenins'ka molod' 1 July 1989: n. pag.

Cherkashyna, L. S. "'Chervona ruta': Perspektyvy rozvytku ukrainskoi estrada." Narodna tvorchist' ta etnohrafiia 2 (1990): 41-44. Print.

Chervona ruta 89. Kyiv: TsK LKSM Ukrainy and Orhanizatsiinyi komitet pershoho respublikans'koho festyvaliu ukrains'koi suchasnoi pisni ta populiarnoi muzyky, 1989. Print.

Derkach, Nadiia. “I znovu u L'vovi - 'Chervona ruta.'” Lenins'ka molod', 1 Aug. 1989: n. pag. Print.

Dziuba, Ivan. "Chy usvidomliuiemo my natsional'nu kulturu iak tsilisnist'?" Kul'tura $i$ zhyttia 24 Jan. 1988: n. pag. Print.

---. “Chy usvidomliuiemo my natsional'nu kulturu iak tsilisnist'?” Nauka i kultura: Ukraina (22) 1988: 309-25. Print.

---. "Strazh cheloveskogo v cheloveke: Literatura i protivorechiia deistvitelnosti." Voprosy literatury (9) 1988: 12-53. Print.

Fedorov, A. "Kakom tsvetom zatsvela “Chervona ruta'?" Pravda Ukrainy 7 Oct. 1989: n. pag. Print.

Ievtushenko, Oleksandr. Lehendy khymernoho kraiu: Ukrains'ka rok-antolohiia. Kyiv: Avtohraf, 2004. 255-57. Print.

Ilin, Oleh. "Khto plekaie sontse - rutu." Prapor iunosti 6 July 1989: n. pag. Kalenychenko, Anatolii. Private letter to the author dated 5 March 2008.

Kobets', Ol'ha. "Chy ie ukrains'kyi shliaher?" [Interview with Ivan Malkovych] Vechirnii Kyiv 1 Dec. 1989: n. pag. Print.

Kryvenko, O. “Stadion Santiago de Chili? Ni - Bukovyna!” Postup 11 Oct. 1989: 7. Print.

13 For information on the 2015 festival see <www.chervonaruta.info $>$. 
---. 'Festyval' prokhodyv v obstanovtsi teroru. Reportazh pro dii militsii i KGB pid chas festyvaliu, shcho poiavyvsia v nezalezhnomu vydanniu 'Postup'." Shliakh peremohy 19 November 1989: 5 . Print.

Kupchenko, 0. "Znaity svoiu Chervonu rutu." Lenins'ke plemia 30 July 1989: n. pag. Print.

Kutsai, Tamara. “Obraz obzhynkiv" Molod' Ukrainy 29 July 1989: 1. Print.

Lepsha, Ivan. "Kvitny slavoiu, 'Chervona ruto'!” Suchasnist' 2 (1990): 33-41. Print.

Lukoms'ka, Iryna and Ilchenko, Liia. "Chervona ruta - ukrains'ka revoliutsiia." Ukrains'kyi kaleidoskop 1 (2000): n. pag. Print.

Mel'nyk, Taras, Anatolii Kalenychenko, and Ivan Malkovych. "Chervona ruta." Literaturna Ukraina 27 July 1989: 8. Print.

---. 'Nazustrich 'Chervonii ruti': Tvorcha kontseptsiia Pershoho respublikans'koho festyvaliu ukrains'koi suchasnoi pisni ta populiarnoi muzyky." Kultura i zhyttia 16 July 1989: 6. Print.

Mishchenko, Maksym. "Pryikhaly z pretenziiamy" Molod' Ukrainy 18 Apr. 1989: $n$. pag. Print.

Orhkomitet pershoho respublikans'koho festyvaliu ukrains'koi suchasnoi pisni ta populiarnoi muzyky "Chervona ruta." "Zvernennia." Kul'tura i zhyttia 16 July 1989: 6. Print.

Petrovs'kyi, V., Chaikivs'kyi, O., Perehinchuk, M. and M. Aksaniuk. "Na konkurs; z chornoho khodu!" Molod' Ukrainy 3 Sept. 1989: 1. Print.

Riabchuk, Mykola. “'Ruta' proty rutyny.” Nauka i kul'tura: Ukraina 24 (1990): 396404. Print.

Rutkovs'ka, O. V. "Pochynaietsia z folkloru, a vidlunuie v dushi." Kultura i zhyttia 15 Oct. 1989: 3. Print.

---. "Polemichni rozdumy pro festyval' 'Chervona ruta'." Narodna tvorchist' ta etnohrafiia 2 (1990): 38-41. Print.

Sharykova, Z. "'Chervona ruta' - kvitka nadii, abo khto poide v Chernivtsi," Kyivs'ka pravda 9 Aug. 1989: n. pag. Print.

Sheremet, Hanna. "'Chervona ruta' shukaie talanty." Vechirnii Kyiv 4 Aug. 1989: 3. Print.

Shtan'ko, S. "Profanatsiia, abo reportazh z prystrastiu z podii, shcho mala b staty sviatom suchasnoi ukrains'koi pisni, a peretvorylasia na vydovyshche, vid iakoho ne znaiesh, kudy ochi podity vid soromu..." Molodohvardiiets' 15 Aug. 1989: n. pag. Print.

Stetsenko, Kyrylo, comp. Pershyi respublikans'ky festyval' ukrainskoi suchasnoi pisni ta populirnoi muzyky. n.p.: Reklama, 1989. Print.

--.. “'Chervona ruta' (notatky z L'vivs'koho oblasnoho vidbirkovoho kontsertu)." AhroPrut, 14 July 1989: 5.

---. "Kyiv zustrichaie festyval'." Molod' Ukrainy 17 Aug. 1989: n. pag. Print.

Stetsenko, Kyrylo. “Kyivs'ka uvertiura." Molod' Ukrainy 27 Aug. 1989: 1, 3. Print.

Stohniienko, 0. "Sviato vidrodzhennia." Molod' Cherkashchyny 25 Sept. 1989: n. pag. Print.

Syliutina, 0. "Khai rozkvitaie 'Chervona ruta'." Komsomolets' Poltavshchyny 3 Oct. 1989: 5. Print.

“Tilky tsyfry ... us'oho na festyvali." Chervona ruta: Visnyk festyvaliu 2 (20 September 1989): 1. Print. 
Tosenko, Iu. “Rok 'Chervonoi ruty'." Komsomols'kyi hart 14 Oct. 1989: n. pag. Print. Tsvirko, Mykola. “'Kobza' v rusli vidrodzhennia.” Vechernii Kyiv September 11, 1990: 3.

Wanner, Catherine. "Nationalism on Stage: Music and Change in Soviet Ukraine." Mark Slobin, ed., Retuning Culture: Musical Changes in Eastern Europe. Durham and London: Duke UP, 1996. 136-55. Print.

---. Burden of Dreams: History and Identity in Post-Soviet Ukraine. University Park, Penn.: The Pennsylvania State UP, 1998. Print.

Zvoryhina, N. "Na festyval' u Chernivtsi." Komsomolets' Zaporozhia 26 Aug. 1989: $n$. pag. Print. 